\title{
Erasmus and the Colloquial Emotions
}

\author{
Brian Cummings \\ University of York, York, UK \\ brian.cummings@york.ac.uk
}

\begin{abstract}
Cognitive philosophy in recent years has made conversation central to the experience of emotion: we recognise emotions in dialogue. What lesson can be drawn from this for understanding Erasmus' Colloquies? This work has often been rifled for its treatment of ideas and opinions, but it also offers a complex and highly imaginative treatment of conversation, originating as rhetorical exercises in De copia. This essay reconfigures the Colloquies in such terms, especially those involving female interlocutors, drawing on the riches of ancient interest in conversation in Plato, Cicero and Quintilian, and also on the vogue for dialogue in Renaissance Italy from Leonardo Bruni to Castiglione.
\end{abstract}

\section{Keywords}

conversation - emotion - recognition - rhetoric - dialogue - women

Le plus fructueux et naturel exercice de nostre esprit, c'est à mon gré la conference. J'en trouve l' usage plus doux que d'aucune autre action de nostre vie. ${ }^{1}$

MiChel De MONTAigne, 'De l' art de conferer', Essais, iii.8

1 Montaigne, Les Essais, ed. P. Villey and V.-L. Saulnier (Paris: Presses Universitaires de France, 2004), p. 922. 
Conversation, Montaigne avers, is the most natural function of the human spirit. A faculty of speaking is the key to the art of living: so much so that he would sooner give up the sense of sight than hearing or speech. Montaigne means by 'la conference', above all, the exercise of spirited debate: he wants someone to disagree with. The mind is invigorated by communication with other vigorous minds. Cicero in De finibus is cited by Montaigne in approving affirmation: Neque enim disputari sine reprehensione potest. 'There can be no debate without contradiction', it appears; although it is also worth noting that Montaigne fails to quote the remainder of Cicero's sentence: 'it is equally impossible to debate properly with ill-temper or obstinacy'. ${ }^{2}$

This passage in De finibus is, of course, well known to Erasmus, who agreed with the latter sentiment as much if not more than with the first. The fine line between controversy and decorum, between wit and discord, is one of the first principles of Erasmus in politics or religion, or in the moral life, or at dinner parties. Conversation is thus an art of agreement as well as disagreement, for which Cicero is once again the champion. Cicero's nemesis Julius Caesar 'surpassed them all' as an orator, he says, because even at the bar he would use his conversational style (sermone) 'to defeat other advocates with their elaborate orations. ${ }^{3}$ Cicero goes on in De officiis to say that conversation:

should be easy and not in the least dogmatic; it should have the spice of wit. And the one who engages in conversation should not debar others from participating in it, as if he were entering upon a private monopoly; but, as in other things, so in a general conversation (in sermone communi) he should think it not unfair for each to have his turn.

For Montaigne in particular, as for the sixteenth century in general, and for some time after, 'l' art de conferer' was embodied in the Familiaria Colloquia of Erasmus. This was first published in November 1518, by Johannes Froben, in an unauthorized octavo of eighty pages, of about a dozen exercises in polite conversation. ${ }^{4}$ In March 1519, Erasmus consented to a revised version by Dirk Martens. By March 1522, as it found definitive form, the book had been reissued around thirty times, in copies printed in Paris, Leipzig, Antwerp, Vienna, Kraków, Mainz, Augsburg, Cologne, and Strasbourg, as well as Basel and Louvain. ${ }^{5}$ The number of the colloquies, and the work's ambition, grew and grew

2 Cicero, De finibus, 1.8.28.

3 Cicero, De officiis, 1.37.133.

4 Familiarium colloquiorum formulae (Basel: Johannes Froben, 1518).

5 Craig R. Thompson, 'Introduction', in CWE 39: xxiv. 
until the edition by Hieronymus Froben and Nicolaus Episcopius in $1533 .{ }^{6}$ By now a full-scale book of dialogues, this edition formed the basis for the posthumous Opera omnia, comprising sixty-one model cases of human interaction in speech.

In the prefatory letter to the March 1519 edition, Erasmus describes the work as consisting of 'phrases useful in daily intercourse and ... conversation over the dinner-table. ${ }^{7}$ Yet in his apology 'To the reader' dated 21 May 1526, appended to most editions as a short treatise, De utilitate colloquiorum, Erasmus says little about the art of conversation, either in theory or practice. Instead, pursued by 'slander', he regrets how these days 'it is not safe to publish any book except under armed guard. ${ }^{8}$ Conversation, it seems, follows its own law of entropy, and by now (as in many matters), Erasmus associated it with the controversies and reprehensions the colloquies had subsequently run into. This reflects the turbulence of the times, and especially of the Luther affair. The faculty of theology in Paris in 1526 identified 69 passages in the book which were subject to error or liable to corrupt the young, and in 1528 the faculties of arts, canon law and medicine lumbered in. ${ }^{9}$ Erasmus' statements on monks, on pilgrimages, or celibacy, or fasting, exposed him to censure: but also, perhaps, the style of the work itself caused trouble, moulded on Horace's Satires, and conceived (as he remarked in 1519) as 'gossip by the fireside after supper'. The book reflects what we feel in 'our off moments, in our cups, in love, or in anger. ${ }^{10}$ Conversation is always like that. Whatever we meant to say, however we understood each other while we were speaking, may be overtaken by mutual misunderstanding. This is, perhaps, an allegory for the intersubjective experience of emotion. Miscommunication, upset, or anxiety, are as much a part of the history of emotion as communication, sympathy, or harmony. 'Our feelings belong to one world', says Proust; 'our ability to name things and our thoughts to another; we can establish a concordance between the two, but not bridge the gap.'11

This, indeed, has been the philosophical justification for the dialogue form since ancient times. Socrates uses the dialectic of conversation to enable us to pursue truth, winnowing off false opinions or glib insights on the way. Some

6 ASD I-3: 771-774 conveniently sets out the progress in contents of the early editions.

7 Ep. 909 CWE lines 14-15.

8 'The Usefulness of the Colloquies', CWE 40: 1097.

9 Craig R. Thompson, Headnote to De utiliitate, in CWE 40: 1096.

10 Ep. 909 CWE lines 71-72.

11 Marcel Proust, The Guermantes Way, trans. Mark Treharne (London: Penguin Books), p. 47. 'Nous sentons dans un monde, nous pensons, nous nommons dans un autre, nous pouvons entre les deux établir une concordance mais non combler l' intervalle'; $A$ la recherche du temps perdu, ed. Jean-Yves Tadié, 4 vols (Paris: Gallimard, 1988), ii.349. 
readers, initially, perhaps, assume that Socrates always speaks with authority, or says what Plato believes. However, all readers have to come to terms with the views expressed by his interlocutors. ${ }^{12}$ In some dialogues, more than one insight or opinion is held in balance, in such a way that it is never resolved what to do with them, as Miles Burnyeat argues is the case in the Theaetetus. ${ }^{13}$ HansGeorg Gadamer goes further: the dialogue form is innately open-ended or even non-committal, or commits us to no more than carrying on thinking. ${ }^{14}$ Mary Margaret McCabe remarks how varied the psychology of conversation in Plato is: 'Likewise, engaged on a conversation, we may find ourselves stepping outside the position we originally occupied and understanding a different point of view'. ${ }^{15}$ Characters talk to each other, interrupt each other; they say what they have been doing, they gossip, they make plans for a walk, or indulge in idle reminiscence. All of this makes a reader think and changes how she feels.

In the humanist revival of classical dialogue in quattrocento Italy, Plato is always in mind, and Marsilio Ficino, especially, imitated his manner (as well as translating him). However, Cicero was more heavily favoured as a technical model for philosophical dialogue. ${ }^{16}$ The fifth book of De finibus is a prime example. Cicero describes, there, attending a lecture in one of the academic schools, and then taking 'an afternoon stroll' with his brother Quintus, his cousin Lucius, and his friend Titus Pomponius. ${ }^{17}$ While Cicero is not exactly renowned for creating convincing fictions of conversation, Malcolm Schofield argues that, more than Plato, he 'gives properly argued alternatives a real run for their money'. ${ }^{18} \mathrm{In}$ providing a formal role for arguments in utramque partem, representing evenhandedly both sides of a case, Cicero leaves debate open. ${ }^{19}$ This is the ethic of debate Erasmus always admires most, as at the conclusion of De utilitate colloquiorum:

12 C. Gill, 'Speaking up for Plato's Interlocutors', Oxford Studies in Ancient Philosophy, 20 (2001): 297-321.

13 M.F. Burnyeat, 'Plato on the Grammar of Perceiving', Classical Quarterly, 26 (1976): 29-51.

14 Gadamer, Dialogue and Dialectic: Eight Hermeneutical Studies of Plato, trans. P.C. Smith (New Haven: Yale University Press, 1980), p. 88.

15 'Plato's Ways of Writing', Oxford Handbook of Plato, ed. Gail Fine (Oxford: Oxford University Press, 2008), p. 105.

16 David Marsh, The Quattrocento Dialogue: Classical Tradition and Humanist Innovation (Cambridge, MA: Harvard University Press, 1980), p. 6.

17 Cicero, De finibus, 5.1.1.

18 Schofield, 'Ciceronian Dialogue', The End of Dialogue in Antiquity, ed. Simon Goldhill (Cambridge: Cambridge University Press, 2009), p. 63.

19 Cicero, Tusculan Disputations, 2.3.9: 'de omnibus rebus in contrarias partes disserendi'. 
let us interpret fairly judgments that differ from our own, neither desiring ours to be accepted instantly as oracles nor taking as oracles the judgements of those who do not understand what they read. ${ }^{20}$

Jacques Chomarat has written the clearest exposition of the idea that Erasmus uses the rhetorical resources of dialogue to achieve persuasive and argumentative purposes. ${ }^{21}$ However, Erasmus also writes conversations where it is not even clear why the interlocutors are talking at all, and whether they achieve anything by the end. As is well known, in this he follows more the alternative classical tradition of dialogue in Lucian. ${ }^{22}$ Along with Thomas More, Erasmus produced a Latin translation of some of Lucian's Greek dialogues in $1506 .{ }^{23}$ In France, 'Lucianisme' became the byword for the satirical style of François Rabelais and Bonaventure des Périers. It is easy to see Erasmus' interest in a similar light. Lucian's Charon or the Observers, for example, has Charon, the ferryman of the dead, leaving hell for the upper world, to ask Hermes about human affairs. Hermes describes what is spread out in a godlike view below him, giving Charon ample opportunity for a mordant commentary on human stupidity and corruption.

'Rash vows' in Erasmus (De votis temere susceptis), the first stand-alone dialogue in Johannes Froben's March 1522 edition, begins in apparently similar vein to Charon:

ARNOLDUS: Where have you been wandering so long?

CORNELIUS: In hell.

ARNOLDUS: Not unlikely, since you've come back to us so dirty, thin, and pale. $^{24}$

Yet there is a kind of pointlessness to the meeting, in some contrast to Lucian's Charon. ${ }^{25}$ For all the world, Arnold and Cornelius are like Estragon and Vladimir, at the beginning of Waiting for Godot. They have nothing to do, and

\footnotetext{
20 CWE 40: 1109.

21 Chomarat, Grammaire et rhétorique chez Érasme, 2 vols (Paris: Les belles lettres, 1981), 2: 877 .

22 David Marsh, Lucian and the Latins: Humor and Humanism in the Early Renaissance (Ann Arbor: University of Michigan Press, 1998), pp. 169-170.

23 Craig R. Thompson, 'The Translations of Lucian by Erasmus and Thomas More', Revue Belge de philologie et d'histoire, 19 (1940), 5-35.

24 CWE 39: 37.

25 In the March edition of 1529, Erasmus included a new dialogue called Charon.
} 
there is nothing to be done. 'Rien à faire.'26 Although Cornelius recounts that he is on the way back from a pilgrimage to Jerusalem, going back home is never so purposeful as setting out for somewhere else. Arnold is franker: only folly has driven him here, just as it has countless others. Cornelius' new religious vow, meanwhile, is merely to enjoy himself more in future. How so, asks Arnold; giving a kind of Freudian answer in the form of a rhetorical question: An quia iucundum est meminisse laborum actum?27 Is it 'enjoyable to recall hardships when they're over and done with?' Yes, in part, Cornelius answers, but adds another advantage: he can tell lies about his travels. Arnoldus and Cornelius share each other's company in invented memory and in creating fictions of themselves. Or perhaps they are just spending time together. At the end, they agree to throw a party sometime else, to share more stories.

We could call this talk for the sake of talking. This throws open the nature of the Colloquies to further discussion. One model for dialogue, favoured by Montaigne, is progress through disagreement. This happens a lot in Plato. Opinions differ, but we find the right one by listening to the opposite. An alternative view is that conversation itself constructs a model for agreement. The interesting point is that both models rely on a theory of emotion. Argument is not just about a rational procedure; it is also about changing people's feelings. Aristotle made this the foundation of his Rhetoric. An orator needs to persuade people, and so he needs (it is always 'he' in Aristotle) to understand emotions, both his own and those of his listeners. ${ }^{28}$ Encountering difference arouses antipathy; soliciting agreement entails sympathy. Modern cognitive science suggests a parallel pattern, mining dialogue analysis to detect emotional content. Indeed, dialogue has come to be a model not just for agreement, but for the successful management of emotions altogether. Let's talk, we say. Only through talk are emotions understood, or perhaps even are comprehensible. This is called 'emotional recognition', or ERC: emotion recognition in conversation. ${ }^{29}$

While Aristotle's Rhetoric came back to the fore only in the generation after Erasmus, in the work of Francesco Robortello, he could have found a similar intuition in Quintilian. In his discussion of figures as arguments, Quintilian says that they have to be based on agreeable and 'credible' emotions. ${ }^{30}$ Con-

\footnotetext{
26 Samuel Beckett, En attendant Godot (Paris: Éditions de Minuit, 1952), p. 9.

27 ASD I-3: 148.

28 Aristotle, Rhetoric, Book III, 1418a7-9.

29 Chul Min Lee and Shrikanth Narayanan, 'Toward Detecting Emotions in Spoken Dialogs'. IEE Transactions on Speech and Audio Processing. 13 (2): (March 2005). 293-303.

30 Quintilian, Institutio oratoria, 9.3.102.
} 
versation, Erasmus would surely recognise, is the place where we deal with our emotions together. What is at issue in the Colloquies, then, may not be the conclusion we come to, but how we got there. What do we learn about each other in the process, and how do we feel now? Once again, Cicero is a model to follow here. In Book II of the Tusculan Disputations, devoted to the problem of pain after the death of his daughter Tullia in childbirth, he describes how his friends leave off rhetorical exercises in the afternoons in order to engage in discussion (disputationes). The effect, he says, is not so much intellectual enlightenment, as that he felt delight and comfort from talking (delectatus vel potius adiutus). ${ }^{31}$ To convey this, Cicero abandons a narrative mode of analysis in order to record the dialogue as if word-for-word, person to person.

Could it be that this is part of Erasmus' aim in the Colloquies? At stake is not only intellectual debate about issues of the time, but what we might now call emotional intelligence about how to deal with them. The Colloquies set in motion brief encounters between scores of characters. Many of them (like Arnoldus and Cornelius) may be based on Erasmus' friends or acquaintances. ${ }^{32}$ What matters is not whether this is 'really' Cornelis Gerard, one of his oldest correspondents (from his time in the cloister at Steyn), but how Erasmus makes him talk. Not all of Erasmus' speakers are very good at it. They are churlish, or short of words, or short of feelings. Others, though, many of them women, are emotionally self-knowing. Some, who understand the emotions of others, are not very good at their own, especially in the heat of the moment. What matters, finally, is not what they individually say, but what comes out in their colloquium, the coming together of their conversation. We might call this, or the work itself, a talking cure.

\section{Rhetoric and Conversation}

Rhetoric is the art of speaking as well as writing well. This is what makes it so general a form of enquiry: it covers, Peter Mack observes, 'the use of voice and gesture, the ways to discover and present arguments, the arousal of emotions, self-presentation, selections of vocabulary, the organization of a speech,

31 Cicero, Tusculan Disputations, 2.4.10.

32 Arnoldus may refer to the Arnoldus Bostius of Ep. 53. A Carmelite of Ghent, he was a friend of Cornelis Gerard, who could in turn be Cornelius. Gerard, an Augustinian canon from Gouda, knew Erasmus by 1489 and probably much earlier; he is the author and recipient of many letters, beginning with Ep. 17 . 
patterning of words and sounds. ${ }^{33}$ Once the grammatical elements have been learned, Erasmus says in De ratione studii, pupils should 'be encouraged to practise speaking right from the start'. ${ }^{34}$ In this he explicitly follows Quintilian. ${ }^{35}$ It is worth recalling here that, while the Colloquies have come to be read, like Praise of Folly, as part of Erasmus' experiment with fictional writing, they are related much more to the rhetorical works. This is where he placed them in his plans for an Opera omnia (in volume 1 rather than in volume 4) ${ }^{36}$ Moreover, as he recalls in his preface to the 1519 edition, the Colloquies began as an exercise in parallel with De copia. ${ }^{37}$ Twenty years earlier, he refers to the existence of conversational exercises (sermones quosdam quotidianos) that he has written for his students, which Augustin Vincent (Caminadus) has collected in a manuscript. ${ }^{38}$ These scraps of dialogue are 'such as we use on meeting each other and at table.39 Indeed, three letters survive of scraps like this, to pupils such as Christian and Heinrich Northoff, who were lodging with Augustin in $1497{ }^{40}$ In a letter to Jacob Batt in 1500, Erasmus offers to revise the spoken samples and enclose them with a draft of De conscribendis epistolis. ${ }^{41}$ This work, too, had a scrappy publishing history: Erasmus wrote a preface to a 'method of writing letters' in 1498, although the work was only printed (unofficially) in 1521 before an 'authorized' edition by Froben in August $1522 .{ }^{42}$ At some level, Erasmus seems to have conceived of these two works as parallel elementary texts in speaking and writing well. There is some cross-over of material in early editions. ${ }^{43}$ In any case, the description of the colloquies as formulae of conversation, 'everyday' or 'familiar', is retained from 1518 to 1522 . He begins, indeed, with a formula for meeting: 'Greetings, father'; 'dear little mother'; 'my brother'44

A colloquium in Cicero is not a natural conversation, but a performance in imitation of the natural. Mark Antony is described in a letter to Atticus (written just after the assassination of Caesar) as making a colloquium cum heroibus

33 Mack, A History of Renaissance Rhetoric 1380-1620, Oxford-Warburg Studies (Oxford: Oxford University Press, 2011), p. 2.

34 De ratione studii, CWE 24: 675 .

35 Quintilian, Institutio oratoria, 1.1.11.

36 Franz Bierlaire, Érasme et ses colloques: le livre d'une vie (Geneva: Droz, 1977), p. 33.

37 Ep. 909 cwe line 19.

38 Ep. 13 o to Jacob Batt, Allen lines 91-93.

39 Ep. 130 cWE line 109.

40 Epp. $54-56$ to Christian Northoff.

41 Ep. 130 CWE lines 110-112.

42 Wallace Ferguson, Headnote to Ep. 71 in CWE 1: 146-147.

43 Thompson, 'Introduction', in CWE 39: xxiv.

44 CWE 39: 7. 
nostris ('with our heroes') ${ }^{45}$ In the Twelfth Philippic, a colloquium is equivalent to a parley of the army, or even a political summit. ${ }^{46}$ What Erasmus means by colloquium is more like what Cicero means by the word sermo - the speech of everyday life, which Cicero often calls sermo communis. Of course, the printed version is an imitation rather than the real thing: it is a written representation of speech, but it harks back to the oratorical nature of rhetorical training. Sermo is the ordinary Latin word for any kind of talk or speaking; however, it also covers literary conversation or discussion (similar to oratio). It can thus be high or low; it can refer to a particular form of style, expression, or diction; it can mean the language of a nation, but it can also refer to a single 'word'. Indeed, the most famous instance of it in Erasmus, and the cause of much controversy, is when he uses it in the 1519 Novum testamentum to translate (in place of Jerome's verbum) the first verse of the gospel of John: In principio erat sermo ('In the beginning was the word'). ${ }^{47}$

Sermo is also a familiar, but complex, word in literary theory. The pseudoCiceronian Rhetorica ad Herennium, the oldest surviving Latin rhetorical treatise, divides out three kinds of sermo (or 'tones of voice') to learn: first, speaking with dignity, 'with the calmest and most subdued voice possible'; second, a 'demonstrative' style, with 'a rather thin-toned voice, and frequent pauses and intermissions', designed to implant in the hearer's mind the points we are making; lastly, a 'narrative' tone, in which 'we seem to recount everything just as it took place. 48 This will require rapid and vigorous intonation in some cases, slower and leisurely in others. Even on such simple lines, sermo has to accommodate further modulations: 'sharpness', 'kindness', 'sadness', or 'gaiety'. Adjustment needs to be made to the emotion of the occasion; or alternatively, to variations of jest: 'shifting utterance smoothly', from the serious to 'facetious', with the hint of a smile, yet no laugh.

Sermo is a still subtler concept in Cicero's authentic method. In the Orator, it is equivalent to an authorial style, such as when he praises Xenophon, cuius sermo est ille quidem melle dulcior, a voice sweeter than honey, one quite removed from the wrangling of the forum. ${ }^{49}$ It can mean a person's distinctive mode of voice, as when Cicero in Brutus praises Laelia, the daughter of Gaius,

\footnotetext{
45 Cicero, Ep. XIV.6.1.

46 Cicero, Philippics, 12.11-12.

47 Marjorie O'Rourke Boyle, Erasmus on Language and Method in Theology (Toronto: University of Toronto Press, 1978), p. 22.

$48 \quad$ Rhetorica ad Herennium, 3.14.24.

49 Cicero, Orator, 9.32.
} 
for her careful usage (elegantia). ${ }^{50}$ In Brutus, it is also used as a synonym for a dialogue, or to refer to discussion in the senate. ${ }^{51}$ In the dialogue between Laelius and his sons-in-law, De amicitia, Cicero chooses sermo as a term to reflect an author's intention in rendering character, 'to create the impression that they are present and speaking in person'.52 It is a commitment of living speech to memory, so that the actors are on stage before us. Its presence, in a crucial context in this work on friendship, demonstrates that for Cicero, sermo is associated with the representation of feeling as much as literary theory; indeed, the two are hardly distinguishable. By rendering these speech acts, Cicero aspires that the reader will believe that Laelius himself is talking. Dialogue thus acts as a mimetic performance of friendship in action, so that 'as you read it you will recognize in it a portrait of yourself'.53 Sermo is the rhetorical performance of self, of emotion, of intersubjectivity.

From one of Erasmus' earliest letters, to his brother Pieter in 1487, sermo describes the familiar talk of friends. It is the language Erasmus shares with his beloved Servatius, when they talk about Pieter together; it is equivalent to a person's thought-processes or even his dreams. Friendship and intimacy are synonymous with it, as is summed up in the word familiares. This is the word Erasmus uses in the title of the Colloquies, of course; it is the word Cicero used for his 'familiar letters' to his friends (as did Petrarch, in turn). ${ }^{54}$ The connection Erasmus makes between familiar speech and friendship could hardly be better expressed than in Cicero's letter to Volumnius Eutrapelus in February or March 5 О ВСЕ: iucundus est mihi sermo litterarum tuarum. ${ }^{55}$ 'I enjoy the way your letters talk.' He might have mistaken the letter, addressed without a first name, for one by the senator Volumnius, but something in the way that it is written reveals his friend's voice. The give-away is expressed by Cicero in a joke in Greek, $\varepsilon \dot{\tau} \tau \rho \alpha \pi \varepsilon \lambda i \alpha$, which means 'cultured insolence', or outrageous wit; this is his friend's eponymous cognomen. Erasmus, who calls himself Desiderius, knows the trick well. Indeed, he includes a Eutrapelus in two of his colloquies, as well as various avatars of himself. ${ }^{56}$ Our words are as expressive of us as our appearance or our very names.

\footnotetext{
50 Cicero, Brutus, LVIII.211.

$51 \quad$ Cicero, Brutus, LX.218.

$5^{2} \quad$ Cicero, De amicitia, 1.4.

53 Cicero, De amicitia, 1.5.

54 Kathy Eden, The Renaissance Rediscovery of Intimacy (Chicago: University of Chicago Press, 2012), p. 49.

55 Cicero, Ep. viI.32.3.

56 In Ars notoria ('The Art of Learning'), 'Desiderius' talks with 'Erasmius', apparently modelled on Johannes Froben's younger son. Various colloquies use the names 'Erasmus' and
} 
The place where these matters are discussed in formal rhetoric is in relation to prosopopoeia. These are called by Quintilian fictiones personarum, which are used to display the inner thoughts of opponents; to introduce conversations between ourselves and others; or 'to provide appropriate characters for words of advice, reproach, complaint, praise, or pity. ${ }^{57}$ Some rhetoricians, he says, distinguish prosopopoeia (where both speech and person are invented) from sermocinatio, or $\delta i \alpha \dot{\lambda} \lambda$ yos (in the Greek nomenclature), which consists of imaginary conversations between historical characters. Quintilian rejects the distinction on extremely interesting grounds: 'for we cannot of course imagine a speech except as the speech of a person'. Impersonation is an inevitable sideproduct of speech-making. It can, of course, be done badly rather than well, yet creating acts of speaking always conveys the imitation of a person as well as a meaning or an idea. This is clearly a principle which Erasmus takes to heart in the Colloquies. He deals with the theory in Book II of De copia, where he defines prosopopoeia as proxima personarum descriptio ('the realistic presentation of persons'). ${ }^{58}$ As well as stock delineations of stereotypes and generic emotions, Erasmus here takes the time to admire more complex delineations of character such as in Lucian's Hippias. He also strays into drama, especially several plays by Terence. Who could be more dissimilar, he asks, than Demea and Micio in Adelphi, the two old brothers who educate their children in such contrasting ways? 'Micio is mild even when he is trying to reprimand his son severely, Demea is cross-patched even when he is doing his best to be pleasant. 59 Unlike Quintilian, Erasmus reserves a different term ('prosopography') for delineating historical characters. The highest form, he says, is dialogue itself: 'in which we supply each person with utterances appropriate to his age, type, country, way of life, cast of mind, and character'.60

\section{Dialogue and Emotion}

The humanist revival of ancient dialogue began in Italy in around $1400 .{ }^{61}$ Petrarch had previously written the Secretum, three books of dialogue between

'Erasmius', causing frequent confusion among early printers; see Thompson in CWE 4O: 1120-1121.

57 Quintilian, Institutio oratoria, 9.2.31.

58 De copia, ASD I-6: 206; CWE 24: 582 .

59 CWE 24: 584 .

6o CWE 24: 586.

61 Marsh, 'Dialogue and discussion in the Renaissance', The Cambridge History of Literary Criticism, vol. 3, ed. Glyn P. Norton (Cambridge: Cambridge University Press, 1999), p. 265. 
himself ('Franciscus') and 'Augustinus', but this had not been circulated in his lifetime and shared some of the ambiguity about dialogue felt by Augustine himself. Contra academicos, written in Cassiacum and the first of Augustine's works to be completed, indeed used the dialogue form to argue that dialogue was inappropriate for the expression of Christianity, since certain knowledge was, after all, attainable. ${ }^{62}$ Christianity in general sees a movement by which, as Gillian Clark puts it, 'sermo became sermon', and conversation became exposition or exhortation. ${ }^{63}$ This is despite the evident debt of Augustine's dialogues to Cicero; Augustine admires In Verrem even as he abjures its method. ${ }^{64}$ Petrarch's Secretum is as much Augustinian soliloquy as Ciceronian dialogue. The pioneer in new form is the Florentine Leonardo Bruni. Dialogi ad Petrum Histrum (1401-1406) represents Florentine notables debating the virtues of Dante, Boccaccio and Petrarch. A scholastic disputatio gives way to polite exchange of viewpoints. A rather different approach is taken in Poggio Bracciolini's Facetiae, in which the conversation of learned men is exposed to analysis, ridicule, and sometimes scandal.

In the early sixteenth century, Italian style in the Ciceronian dialogue tended towards the didactic. ${ }^{65}$ Everything changed with Baldassare Castiglione's Il Cortegiano (1528). While formally Ciceronian (modelled on De oratore), Castiglione's characters aspire to a courtly virtue and grace quite removed from the antique Roman urban constitution. The highest rhetorical art of the courtier is sprezzatura, nonchalance and effortlessness. ${ }^{66}$ While most of Erasmus' colloquies were written in the same decade as Castiglione, they have almost nothing in common. Instead they hark back to the humanist quattrocento style of Leon Battista Alberti. Della famiglia, written in the vernacular, uses dialogue in the moulding of virtuous character; but Momus (c. 1450) is more varied, at times melancholic or pessimistic in mood. It follows the Lucianic mode in using the Homeric gods to provide models for human emotion. ${ }^{67}$ In this way Momus shows a mixed attitude to human character, on display even more in the earlier Intercenales (1439), ten books of dialogue in conscious imitation of

\footnotetext{
62 Augustine, Contra academicos, 2.9.22; CSEL, 63: 38-39.

63 Clark, 'Can we talk? Augustine and the possibility of dialogue', End of Dialogue in Antiquity, ed. Goldhill, p. 118.

64 Contra academicos is perhaps based on Cicero's Academica; and De beata vita on Cicero's De finibus and Tusculan Disputations; see Clark, p. 118n.

65 Virginia Cox, The Renaissance Dialogue: Literary Dialogue in Its Social and Political Contexts, Castiglione to Galileo (Cambridge: Cambridge University Press, 1996), pp. 63-69.

66 Peter Burke, The Fortunes of the Courtier: The European Reception of Castiglione's Cortegiano (University Park: Penn State University Press, 1995), p. 11.

67 Marsh, Lucian and the Latins, p. 77.
} 
Lucian. These 'dinner pieces' (to use Marsh's translation) are personal as well as satirical. ${ }^{68}$ 'The Orphan' deals with family litigation over inheritance; in 'The Love Affair', a mother and daughter drive a young man to despair. In 'The Husband', a virtuous husband punishes his unfaithful wife by gaslighting her with silent shows of tolerance. In leading her to her death, the dialogue concludes opaquely, the husband 'combined severity with supreme indulgence', a form of black irony into which Alberti's authorial persona completely disappears. ${ }^{69}$

Erasmus takes this mode further by removing any kind of narratorial intervention. Characters speak for themselves, respond as themselves, and the reader has to take them at their word. Dialogue, that is, becomes the sole medium through which emotion is interpretable, as in a play, although here outside drama. The section on emotion at the conclusion of De copia explains how this happens. Any kind of argument, any kind of literature, even the exposition of facts, can be enhanced by sermocinatio ('dialogue'), 'in which we assign suitable utterances to one or more persons. ${ }^{70}$ Erasmus cites a series of examples from the Iliad, in which Homer demonstrates wonderful skill in delineating 'what is appropriate to each character' through speech. Historians do this frequently, and even Christian writers on occasion. ${ }^{71}$ An extended form may be called epidiegesis, a term Erasmus uses rather differently from the rhetorical tradition, to mean an expanded or repeated or digressive narration, 'done to rouse indignation or sympathy'. The reason for doing this, Erasmus says, is that 'different people are affected by different things' (quod alios alia mouent)..${ }^{72} \mathrm{We}$ could add that people feel different things in the same circumstances.

Erasmus' exposition of the experience of emotion, like many of the best passages in De copia, itself comes upon us as a surprise aperçu, a thought or remark in passing. This ushers forth a copious flow of examples of 'warmth of emotion' from Cicero's Pro Milone, which Cicero mixes in via conversational example (deinde miscet affectus). Plato in The Republic is also apt in it, Erasmus maintains, especially when he wants to get something across which a reader might be reluctant to accept. This is the special skill of writers, who 'handle the various emotions at all the appropriate points' (et affectuum omne genus per omnes locos tractetur). ${ }^{73}$ Erasmus cites Aristotle and Quintilian here, with-

68 Alberti, Dinner Pieces: A Translation of the Intercenales, trans. David Marsh, Medieval \& Renaissance Texts \& Studies, 45 (Binghamton, NY: Renaissance Society of America, 1987).

69 Alberti, Intercenales, trans. David Marsh, p. 133.

70 ASD I-6: 272.

71 CWE 24: 649-65o; Erasmus cites 2 Maccabees 7, and Ambrose's Life of St Agnes.

72 ASD I-6: 272; CWE 24: 65 O.

73 ASD I-6: 276; CWE 24: 654 . 
out giving a reference; presumably he means the passage in Rhetoric, Book III, where Aristotle states: 'The style will be appropriate if it expresses emotion and character corresponding to the subject matter. ${ }^{74}$ Aristotle evokes a distinction between $\hat{\eta} \pi \alpha \theta \eta \tau i x \eta \dot{~} \tau \varepsilon$ xai $\eta \dot{\theta} \theta x \dot{\eta}$, which makes Erasmus pause a little in his swift exposition. The poets are wonderful at this, he says. However, instead of treating (as Aristotle does) $\pi \dot{\alpha} \theta \eta$ as 'emotion' and $\eta \ddot{\theta} \eta$ as 'character', Erasmus makes them apply to different gradations of feeling. The former he calls vehementiores and the latter moderatiores. While partly a question of degree- the more 'passionate' emotions are associated with anger or indignation-Erasmus also makes the casual observation that these are found especially in the Iliad and in tragedy, while the 'calmer' ones proliferate in the Odyssey and in comedy. ${ }^{75}$ This is because qui delectant potius quam perturbant - they please rather than disturb. ${ }^{76}$

In what is by any standard a remarkable piece of literary criticism, Erasmus adds an extraordinary addendum that the 'emotions of comedy' (affectus comicos) are often interspersed into the Iliad and into Greek tragedy as well, although this is less often the case in Roman tragedy. We must, he says, include pleasure in a theory of the emotions (Inter affectus autem ponenda delectatio). To show what he means he makes an extended analysis of the passage in Iliad 6 when Hector departs for battle at the gates of Troy. ${ }^{77}$ Andromache carries in her arms their infant son; Hector smiles without saying anything; Andromache stands close to him, puts out her right hand, and calls him by name. They mouth something to each other, but the boy Astyanax is terrified by his father's armour. Father and mother both laugh; Hector takes off his helmet, puts it on the ground, and kisses the child. No one can get enough of Homer in this mood, Erasmus says, showing his own delight in reading as he retells. He confirms via Horace: thus 'characters seem real' (morata recte) ${ }^{78}$

While this is an idiosyncratic reading of $\ddot{\eta} \theta \eta$ in Aristotle, it can be made sense of, if we think of Erasmus as using it to define habitual behaviour rather than extraordinary. This is, we might say, following Michel de Certeau, 'the practice of everyday life. ${ }^{79}$ It is backed up by the account of ethos in Quintilian, which Erasmus surely has specifically in mind. This is feeling which is 'not only mild and calm, but usually attractive and polite, and pleasing and delightful to the

74 Aristotle, Rhetoric, 3.7, 1408a10-11.

75 Erasmus uses Quintilian 6.2.20 and Longinus 9.15 on this point.

76 ASD I-6: 276; CWE 24: 654 .

77 Homer, Iliad, 6: 369-39o.

78 Horace, Ars poetica, 319.

79 De Certeau, L'Invention du quotidien (Paris: Gallimard, 1980). 
listeners' ${ }^{80}$ This produces an expression of emotion almost without mediation: quo mores dicentis ex oratione perluceant et quodam modo agnoscantur ('so that the speaker's character shines through his speech and is somehow recognized'). This sentence is so perfectly resonant with Erasmus' aim and execution in his Familiaria colloquia that it might serve as its epigraph. Characters there recognise each other's feelings in the act of conversation, caught in the moment of normal everyday situations, and the reader shares this process of emotional recognition in the pleasure of reading. Take De captandis sacerdotiis ('In Pursuit of Benefices'), another early colloquy, between Pamphagus ('omnivorous') and Cocles ('one-eyed'). The name Pamphagus is taken from one of Actaeon's hounds in Ovid's Metamorphoses; it was later used also by Bonaventure des Périers in his Lucianic dialogue Cymbalum mundi. Cocles is one of Erasmus' nicknames for his scribe, Pieter Meghen.

The outward subject for the colloquy is Pamphagus' need for a benefice to keep him in money. 'A monkey without a tail is a priest without a benefice' was a Franciscan period joke. ${ }^{81}$ However, much of the conversation in Erasmus is taken up with Cocles' jokes about Pamphagus' huge nose. ${ }^{82}$ It could be used to extinguish a lamp; to collect things out of holes; as a peg, as a bellows, as a shade from the sun, or as a shield in battle. Pamphagus is remarkably forebearing at the onslaught: 'Lucky me!', he says, when he might be excused for losing patience at what is presumably a sore point as well as a very old gag. ${ }^{83}$ The priest and his old drinking companion get along fine. Indeed, Pamphagus can laugh at himself as well as give back in kind. Nihil est nisi nasus, he replies at one point; you're all wit/nose. ${ }^{84}$ They banter about priests and sex just as easily. Right at the end of the exchange, however, they share some thoughts on humour itself. Ludus in seria, says Cocles. 'You take a serious matter lightly', Thompson translates. We are into the heart of Erasmian territory, and the thought could as easily be reversed. Yet what is also at stake suddenly is how the two friends think about each other. Are the jokes beginning to hurt?

PAMPHAGUS: You mock me and make fun of me. You treat me jokingly in a matter that's not funny at all.

COCLES: I'm not laughing at you; I'm telling the simple truth. I don't joke; I'm telling you straight. I speak seriously, sincerely, plainly. I'm telling the truth.

8o Quintilian, Institutio oratoria, 6.2.13.

81 A.J. Krailsheimer, Rabelais and the Franciscans (Oxford: Clarendon Press, 1963), p. 66.

82 This nose's vast afterlife extends from Cyrano de Bergerac to Tristram Shandy, 3.27-42.

83 Colloquies, CWE 39: 47 .

84 ASD I-3: 154 . 
Pamphagus manages to relax and take it all in good sport. Cocles will never stop playing the clown, Pamphagus says, and so he will not believe a word he says, in return. They break off.

We could call the moment metacolloquial. We are hardly going to trust Erasmus when he has someone say: Serio loquor. Ex animo loquor. Simpliciter loquor. Vera loquor. You must be kidding. Yet the passage also provides a commentary on the section on emotion at the end of De copia. It is a reminder that Erasmus, for all his love of Euripides, makes all his own personal literary ventures in comedy. He seeks, in Quintilian's phrase, to write in a way that is amabile et iucundum. ${ }^{85}$ It is worth remembering, too, that the passage on ethos in Quintilian precedes the one on laughter. ${ }^{86}$ Comedy is the art of the everyday. Yet literary theory has often been very poor at understanding the significance of this, or at having anything moderately interesting to say about comedy. Freud, some say, is an exception, and he certainly is one of the few writers who has tried to understand the quick passage of feeling shown between Pamphagus and Cocles here, between hostility and amiability. ${ }^{87}$ Yet comedy in the Colloquies should not be equated, as it sometimes is, with satire. Quam impia, quam spurca, quam pestifera scripsit Pogius?88 So Erasmus wrote of Poggio's irreverent Facetiae in the letter to Dorp. Erasmus is interested as much in a different kind of comedy, such as is evident in the quick slippage of emotion in conversational exchange. Pamphagus and Cocles understand each other intuitively, but that does not mean they are incapable of hurting each other. Emotion, it turns out, is all about communication, but also about a lack of it.

Of the upwards of one hundred and twenty interlocutors in the Familiaria Colloquia, a dozen are women. The figure is not so remarkable, perhaps, until we realise that in the whole classical tradition of dialogue, the only women characters are Diotima in the Symposium, whose speech is merely reported, and Lucian's Dialogues of Courtesans. Virginia Cox has outlined in detail how the incorporation of female speakers alongside male is one of the 'great novelties'

85 Quintilian, Institutio oratoria, 6.2.13.

86 Quintilian, Institutio oratoria, 6.3.1.

87 Freud, Jokes and their Relation to the Unconscious (Harmondsworth: Penguin Books, 1976), p. 143 .

88 Ep. 337 Allen line 336. As ever, it is not clear whether Erasmus really disapproves of this. 
of Italian Renaissance dialogue. ${ }^{89}$ This is announced with a flourish by Pietro Bembo's Gli Asolani (1505): in the preface to the third book, Bembo defends the inclusion of female speakers in a philosophical dialogue, against those who think this outside the 'proper' offices of the sex..$^{90}$ Castiglione then included Elisabetta Gonzaga, the duchess of Urbino, and her witty sister-in-law, Emilia Pio, in Il Cortegiano. Typically, other women in Italian dialogues belong to a court culture where female manners played a distinctive role; Battista Sforza appears in a 1462 Latin dialogue by Martino Filetico. Another trend observed by Cox is that of the 59 Italian dialogues she has found with female speakers, two-thirds describe known historical figures. ${ }^{91}$ Erasmus is different. Although editors have been keen to find the names of Erasmus' characters among people known from his life, they do not appear in the Colloquies as historical characters. Nor are they presented as types: they are invented fictional people with their own individual ethos. It is interesting that Ortensio Lando, and Sperone Speroni, who experimented with female characters outside of courtly society, were reformist Erasmians. Later, women writers such as Chiara Matraini (Dialoghi spirituali) freely presented a female religious superior instructing an adolescent male. ${ }^{92}$

The August 1523 edition contains five colloquies on love, marriage, sexuality, and what we might loosely call feminism: 'Courtship', 'The Girl with No Interest in Marriage', 'The Repentant Girl', 'Marriage', and 'The Young Man and the Harlot'. To these were added in later editions 'The Abbot and the Learned Lady' (1524), 'The Epithalamium of Pieter Gillis' (1524), 'The New Mother' (1526), 'A Marriage in Name Only' (1529), and 'The Council of Women' (1529). These ten dialogues constitute what Thompson calls a 'marriage group', and Erika Rummel, more robustly, 'Erasmus on Women. ${ }^{93}$ Such texts from a man who was famously a monk, and never married, have caused comment. From here, scholars have attempted to glean Erasmus' own views, or those of Renaissance humanism, on such topics. Rummel advises caution: different characters contradict each other, and indeed sometimes themselves; Erasmus deliberately allows them to repeat clichés, or outrageous views, or obvious non sequiturs. ${ }^{94}$

\footnotetext{
89 Cox, 'The Female Voice in Italian Renaissance Dialogue', $M L N 128$ (2013): 53-78, this ref. 53.

90 Bembo, Prose e rime, ed. Carlo Dionisotti (Turin: UTET, 1966), pp. 181-182.

91 Cox, 'The Female Voice in Italian Renaissance Dialogue', 54.

92 Janet Smarr, Joining the Conversation:Dialogues by Renaissance Women (Ann Arbor: U of Michigan $\mathrm{P}$, 2005).

93 Thompson, Headnote to 'Courtship' (Proci et puellae), in CwE 39: 256.

94 Rummel, Erasmus on Women (Toronto: University of Toronto Press, 1996), pp. 3-4.
} 
Even in his declamation Encomium matrimonii (1518), Erasmus disclaimed responsibility for any views contained within. ${ }^{95}$

Rather than looking for an argument about marriage which Erasmus is trying to inculcate, Reinier Leushuis suggests, we should see in the colloquies a 'mimetic' function, in which the reader is brought to a matrimonial ideal based on intimacy and dialogue. ${ }^{96}$ Here I am interested not so much in marriage per $s e$, as in a model of intimacy expressed in dialogue itself. This is not so much representative as constitutive. For, as cognitive philosophy has been arguing for a while, conversation is not a mimetic processing of emotions first experienced elsewhere, but the place where emotion takes place. Several kinds of metanarrative thus emerge within a colloquy, such as: how far the fictional characters have become people we believe in, or who believe in themselves, or in each other? In so far as we are concerned with argument, it is also about how to make arguments, or even what an argument is. All of this is part of the talking cure.

In the case of the marriage colloquies, there is also an element of sexual play involved in the argument. Proci et puellae is usually translated as 'Courtship', which does not quite capture the frisson, in the Latin, of 'wooers and girls'. Pamphilus discusses with Maria the ethics of sex and marriage; but Pamphilus is also evidently in love with Maria. Maria, in turn, while not returning the favour, enjoys flirting with him. Debating about love is a proxy form of sexual tension, in which argument creates its own frictional excitement, in the way Freud describes so well in his discussion of double entendre. ${ }^{97}$ This indeed is how the dialogue opens, with a play on Maria's own name, as a servant of Mars, the god of war. You're killing me, says Pamphilus, with the usual sexual association. Maria replies with her own form of blood sport:

MARIA: Bona verba. Ubinam strages ista mortalium, quos ego occidi? Ubi sanguis interfectorum? ${ }^{98}$

The double meaning of bona verba is as if to say, well said, but also watch what you're saying, or be careful what you wish for. Pamphilus replies he has turned into a corpse, and wants Maria to bring him back to life. His name is taken

95 In Praise of Marriage, CWE 71: 91-92.

96 Leushuis, 'The Mimesis of Marriage: Dialogue and Intimacy in Erasmus's Matrimonial Writings', Renaissance Quarterly, 57 (2004), 1278-1307.

97 Freud, Jokes and their Relation to the Unconscious, pp. $75^{-76}$.

98 ASD I-3: 277. 'Mind what you're saying. Where's this heap of men I've slain? Where's the blood of the slaughtered?', CWE 39: $25^{8}$. 
from Terence's Andria, where Pamphilus is caught between betrothed lovers, and Erasmus begins this colloquy as if indeed in the middle of a play. The characters are already known to each other and to us, and by now the audience is laughing at the talk of resurrected male bodies. Maria replies with a sub-sense of blood rising to the genitals:

MARIA: Yet this pallor is streaked with lavender. You're as pale as a ripening cherry or a purple grape.

The chafing now quickly turns to neo-Platonism. Again, the role-playing is intricate. Pamphilus is a student of philosophy, evidently, and struts his stuff with plenty of references to Plato (from Phaedo, Philebus, and Phaedrus), and to Ficino (from the commentary on the Symposium). Yet it is Maria who plays Socrates, running rings round him while he shows off his knowledge. It is not unlike, in its way, the treatment of Socrates by Alcibiades in Plato, where he tells his master that he only likes to win the argument in order to get off with the best-looking boys. ${ }^{99}$

MARIA: Dic tu, philosophe. ${ }^{100}$

Her questions show that she knows her theory of the soul, or of accidents or properties, but she also insists on tormenting Pamphilus ('Why do you sigh? Speak freely'), while also teasing him to death with statements of the obvious ('Well, I'm a girl, not a stone'), which are yet reminders of the flesh. In the best tradition of erotic arguments set in schoolrooms, every reference to the body is a return of the repressed, even as the hapless lover tries to keep his mind on higher things. It could be Maria versus Malvolio; indeed, it is perfectly plausible that Shakespeare read this colloquy in Nicholas Leigh's translation, $A$ modest meane to mariage (London, 1568).

What does speaking say? There is more to words, as J.L. Austin's theory of speech acts proclaims, than content alone, such as: 'the fun of discovery, the pleasures of co-operation, and the satisfaction of reaching agreement.'101 Pamphilus and Maria yearn for satisfactory agreement in more ways than one. Like at the end of a Shakespeare comedy, Maria's final words are a put-down, or at least they play for time. She will not marry him yet-it is traditional after all,

99 Plato, Symposium, 222E6.

100 ASD I-3: 279. 'You tell me, professor' is Thompson's nice translation, CWE 39: 259.

101 Austin, 'A Plea for Excuses', Philosophical Papers, 3rd edition (Oxford: Clarendon Press, 1979), p. 175 . 
for the man to propose-and she even wonders if it is best to leave marriages to parental arrangement. She says this by means of a philosophical argument, in keeping with the whole colloquy:

MARIA: But first ponder your own private decision. Judge by your reason, not your feeling. What emotion decides is temporary; rational choice generally pleases forever.

Quod affectus decernit, temporarium est. ${ }^{102}$ Like many statements in the colloquies, this can be taken in the opposite sense. In the final equation, as in Plato, affectus must give way to ratio. However, it is also the case that the temporariness of emotion, its fitness to the moment, is exactly what gives it force. Maria speaks at two levels. She uses the voice of reason to deflect Pamphilus' importunate advances. Yet she remains the mistress of his emotions, by understanding within the moment.

In an artful reply to the theologians in Paris who denounced several points in this colloquy, Erasmus asked with which of the interlocutors, Pamphilus or Maria, he is assumed to identify. The question is artful because, of course, the theologians assume he identifies with the man. Yet while it appears that Pamphilus argues for the superiority of sexual intercourse in marriage above celibacy among priests, it is Maria who questions this. ${ }^{103}$ Erasmus claims implicitly to side with her, even though she does so with decidedly mixed feelings. Beyond this, Erasmus makes another stance against the Paris theologians. This is that the Colloquies are in any case a work of fiction. ${ }^{104}$ The statements within it are not propositional but contingent and imaginative. In that sense, they also belong to a world of emotion, in which agreement is made on different grounds.

Yet this is not to say that nothing really happens in fiction. Take Terence's play Adelphi, to which Erasmus turns again and again, where the brothers Demea and Micio are engaged in a fiction of parenthood, and in which Aeschinus engineers his own feelings to help his brother Ctesipho. This does not diminish what is at stake in the feelings between them. In the midst of mutual deception, Micio's declaration that he loves Aeschinus like a father, even though we know he is not his father, is nevertheless real: nam te amo, quo magis quae agis curae sunt mihi ('I love you, and so I care all the more about what you do'). ${ }^{105}$

\footnotetext{
102 ASD I-3: 287; CWE 39: 267.

103 See Thompson in CWE 39: 276.

104 Erasmus, Declarationes ad censuras Lutetiae vulgatas, LB 9: 9370.

105 Terence, The Brothers, 680.
} 
Erasmus' Philodoxus ('The Lover of Glory'), probes the experience of emotions in plays. Erasmus makes the eponymous interlocutor Philodoxus confess:

PHILODOXUs: Non sum Stoicus $\dot{\alpha} \pi \alpha \theta \dot{\eta} \zeta$ : tangor humanis affectibus. ${ }^{106}$

'I'm not a dispassionate Stoic, I am subject to human feelings.' Yet how to read his own feelings, never mind those of others? The case of Demea in Adelphi, says his friend Symbulus, shows how changeable emotions are. Everyone is different: est singulis in vno quoque genere peculiare quoddam ingenium ('each individual in any one group has some particular characteristic'). ${ }^{107}$ So, do you want me to act like the changeable polypum, asks Philodoxus, ever aware of his honour? In Adagia, this is indeed Erasmus' recommendation: human nature should be adaptable, like the octopus that changes colour according to habitat. ${ }^{108}$ We remain true to ourselves, while accommodating ourselves to every new circumstance. This is what it means to be subject to humanis affectibus.

Reading emotions, according to Erasmus, is precisely the art of rhetoric. As Cicero remarks in Brutus: 'what skill the orator has in playing on the minds of his audience is recognized by the emotion produced. ${ }^{109}$ The intelligence of emotions is immediate, like the sound made by the harp when the string is struck. A good critic can tell a good orator via a single glance, without even hearing a word. Indeed, in 'A Feast of Many Courses', Erasmus describes how emotions can be read without words, through mime or gesture. A woman easily knows what her husband is feeling, without asking. ${ }^{110}$ In Amicitia ('Friendship'), the 'sympathy' between Sir Thomas More and his monkey is recounted, proving that animals, too, feel emotions. In the meadow or in the stable, a horse will seek out always the same companion, when it has nothing to do with sex.111

Many theories of emotion and language, like other theories of language, are based on a model of communication. ${ }^{112}$ I have a feeling, which I try to communicate in words, perhaps in direct response to your entreaty: 'Tell me what you are feeling'. Yet we are also familiar with situations in which words, more than anything, are awkward to find in relation to the complexity of emotion. Perhaps this is especially true of difficult or negative or conflicted emotions.

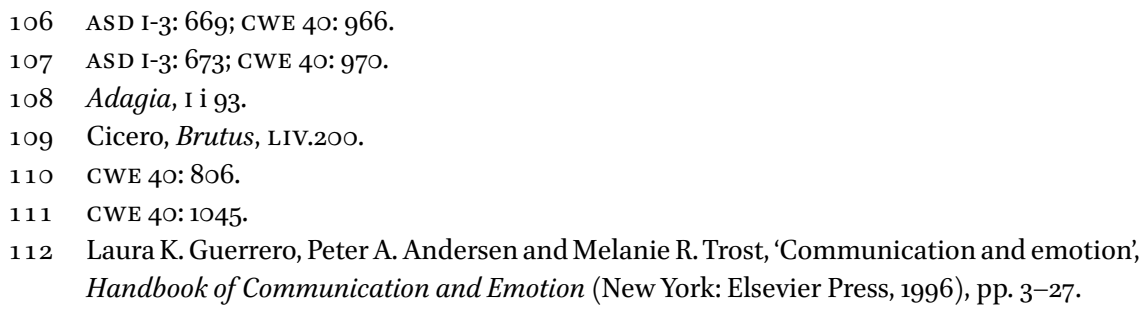


Martha Nussbaum argues in Anger and Forgiveness that intimate relationships are pivotal in this, because of 'people's sense of what it is for their lives to go well'.113 The desire to talk may exceed the ability (I only know that I am feeling something strongly, not what I am feeling precisely). It is also commonplace to say that it is only in the act of talking that we come to know what we feel. In that sense, language is a premonition of feeling, or at least the understanding of feeling: it does not yet have something to communicate. Anger, upset, or distress, inhibits self-knowledge.

Erasmus is more sensitive to these areas than we might think. He explicitly discusses tragedy in De copia as the place where emotions that are vehementiores (like anger or resentment) are on display. Yet he also suggests that everyday emotions (moderatiores) also need careful handling and nurturing. To this end, in the Colloquies, he often chooses his interlocutors precisely because they are not alike, or do not agree, or are actively in conflict with each other. Presentation of emotion in philosophical discussion often assumes self-knowledge. Yet not everyone is as self-knowing as Maria in Prociet puellae. Catarina, in 'The Girl with No Interest in Marriage', argues against sex, but she does so without understanding what sex is. Xanthippe in Coniugum ('Marriage') is not as intelligent as Maria, but she is clearly smarter than her husband. Fabulla in Puerpera ('The New Mother') perhaps shows a different trait, so that even in arguing difficult philosophical problems (freedom and divine justice), emotional intelligence outwits rational knowledge. Eutrapelus, that inveterate mansplainerhis name synonymous with wit - cannot see it for the life of him.

Women are often said to be better at handling emotions, as also at talking about them, than men. Perhaps Erasmus agrees, but if so, he also knows that most conversations inevitably take place between people of unequal emotional intelligence. In these situations, it is as hard to be the person who is expected to be good at talking, as the one who is not. Perhaps there is no better example of this in Erasmus than Magdalia's encounter with Antronius in Abbatis et eruditae ('The Abbot and the Learned Woman'). If Magdalia is often associated with More's daughter, Margaret Roper, Antronius has a lower reputation. Antronius asinus was proverbial for someone exceptionally gross and stupid. ${ }^{114} \mathrm{He}$ is a fat abbot, not much of an academic. Editors, academics themselves, assume that we are not supposed to like him. Yet it is not so clear that Magdalia is in such company. Antronius plays, perhaps, at being a fun-loving Philistine; while Magdalia plays at being his Socrates, bringing him up to scratch. Yet in this supposed

113 Martha C. Nussbaum, Anger and Forgiveness: Resentment, Generosity, Justice (Oxford: Oxford University Press, 2016), pp. 93-94.

114 Adagia, II v 68. 
dialogue of the deaf, between an unmarried man and a married woman, one cloistered and the other not, there is nonetheless an unconscious rapport, so that they can virtually finish each other's thoughts. It is a miraculous example of Erasmus' facility for dialogue in action, grounded in the stylistic device of stichomythia, much used by his beloved Euripides, yet here in virtuoso pairs or trios of words:

ANTRONIUS: I haven't the leisure.

MAGDALIA: How come?

ANTRONIUS: Because I've no free time.

MAGDALIA: No free time to grow wise?

ANTRONIUS: No.

MAGDALIA: What hinders you? ${ }^{115}$

Magdalia tries to persuade Antronius of her own love for books; Antronius replies that books drive him mad. What book-lover would not agree, to a point? He prefers his wine, but while Magdalia loves to scold him about that, it is not clear that she dislikes him, quite the contrary. The apparent empathy between these unlike souls is captured beautifully by an elegant example of Erasmian use of figures of speech. Magdalia employs the device of interruptio on Antronius:

ANTRONIUS: If wisdom came without hard work-

MAGDALIA: But man gets nothing in this life without hard work. ${ }^{116}$

Aposiopesis in Rhetorica ad Herennium is defined as 'to begin to say something and then stop short'.17 It is a form of emphasis, by leaving something obvious unsaid. Quintilian reserves it for an 'interruption' proper (citing Cicero's term, reticentia) in order to show emotion, especially anger or anxiety. ${ }^{118}$ Yet Magdalia employs it instead to show understanding in the very moment of recognition. She finishes Antronius' sentence for him, although not quite in the way that he wanted. She understands him, we could say, better than he does himself. On the same page she then interrupts herself, yet not out of exasperation, or even in Ciceronian 'reticence', but because her thought is catching up with her own feeling. Conversation is like that in Erasmus. It is a way of reconciling tensions,

\footnotetext{
115 ASD I-3: 4O4; CWE 4O: 5 O2.

116 ASD I-3: 4O6; CWE 40: 504 .

117 Rhetorica ad Herennium, 4.54.68.

118 Quintilian, Institutio oratoria, 9.2.54.
} 
or at least of understanding them better. However, even if a conversation of this kind only reveals that there is disagreement, progress of a kind has been made: difference has been communicated, as well as argument registered. Emotional intelligence, in his time as in ours, is perhaps less common than we would like to think. But we will only get there by talking. 